\title{
LUT
}

Lappeenranta

University of Technology

\section{Carbon handprint - An approach to assess the positive climate impacts of products demonstrated via renewable diesel case}

Grönman Kaisa, Pajula Tiina, Sillman Jani, Leino Maija, Vatanen Saija, Kasurinen Heli, Soininen Asta, Soukka Risto

This is a Final draft version of a publication

published by Elsevier

in Journal of Cleaner Production

DOI: $\quad 10.1016 /$ j.jclepro.2018.09.233

Copyright of the original publication: (c) 2018 Elsevier Ltd.

Please cite the publication as follows:

Grönman, K., Pajula, T., Sillman, J., Leino, M., Vatanen, S., Kasurinen, H., Soininen, A., Soukka, R. (2018). Carbon handprint - An approach to assess the positive climate impacts of products demonstrated via renewable diesel case. Journal of Cleaner Production, Vol. 206, pp. 1059-1072. DOI: 10.1016/j.jclepro.2018.09.233 
Word count 9755

\title{
Carbon handprint - an approach to assess the positive climate impacts of products demonstrated via renewable diesel case
}

\author{
Kaisa Grönman ${ }^{\mathrm{a} *}$, Tiina Pajula ${ }^{\mathrm{b}}$, Jani Sillman ${ }^{\mathrm{a}}$, Maija Leino ${ }^{\mathrm{a}}$, Saija Vatanen ${ }^{\mathrm{b}}$, Heli Kasurinen ${ }^{\mathrm{a}}$, Asta \\ Soininen ${ }^{\mathrm{c}}$, Risto Soukka ${ }^{\mathrm{a}}$
}

a) Lappeenranta University of Technology, P.O. Box 20, FI-53851 Lappeenranta, Finland

b) VTT Technical Research Centre of Finland Ltd, P.O. Box 1000, FI-02044 VTT, Finland

c) Neste Corporation, P.O. Box 310, FI-06101 Porvoo, Finland

*) Corresponding author

\begin{abstract}
The capacity to calculate and communicate the beneficial environmental impact of products and services is lacking in scientific guidelines. To fill this gap, this article presents a new approach for calculating the carbon handprint of products. The core of the suggested approach involves comparing the carbon footprint of an improved product with the carbon footprint of the baseline product, and subsequently calculating the reduction in greenhouse gas emission that can be achieved by utilizing the improved product. The proposed approach is founded on the standardized life cycle assessment methodology for footprints until the use stage, and it provides a framework to recognize the effects of the remaining life cycle stages in the actual operational environment. This calculation is meant to be used by manufacturers that wish to show potential customers the positive climate impacts offered by the manufacturer's product. The carbon handprint approach complements the existing methodologies by introducing new definitions and consistent guidelines for comparing the baseline product and the improved product.

This article presents the developed calculation approach and demonstrates the approach with one case study about renewable diesel. Results of the diesel handprint calculation indicate that a driver can reduce greenhouse gas emissions by choosing renewable diesel over baseline fuel. Thus, the producer of the renewable diesel will create a handprint.

Organizations can use carbon handprints for quantifying the greenhouse gas reductions their customers can achieve by utilizing the product. Thus, the carbon handprint can be a powerful tool in communications and marketing. By conducting carbon handprint assessments, a company can also find out how their product qualifies in comparison to baseline products. Therefore, carbon handprints can also support decision-making and lifelong product design.
\end{abstract}

Keywords: handprint; footprint; carbon handprint; carbon footprint; positive environmental impacts; life cycle assessment 


\section{INTRODUCTION}

Assessing environmental impacts has traditionally focused on measuring and modeling the negative effects that products, services, and companies cause to the environment. In many organizations, it is already common to assess resource use or emissions caused as a result of their activities. These assessment practices are thoroughly guided with standards established for life cycle assessment (LCA) (ISO 14040, 2006; ISO 14044, 2006), carbon footprint (ISO, 14067, 2018) and water footprint (ISO 14046, 2014).

Many companies, especially in developed countries, already have a depth of environmental know-how and so succeed in conducting their operations with efficient resource use and producing a minimum amount of emissions and waste. Indeed, these companies might even pursue a business concept that is based on providing products, services or technologies that reduce the environmental impacts of their customers. However, these cleantech or frontrunner companies are lacking a recognized method of calculating and communicating the environmental benefits of their actions.

Scientists have suggested methods for measuring the positive environmental impacts of product systems. Čuček et al. (2012) introduced the concept of total environmental footprint which considers a (product) system's total effects on the environment by summing the direct footprint - the burdening of the environment, and the indirect footprint, the unburdening of the environment. The beneficial unburdening effects in the system can result from substituting harmful products for benign products, such as substituting fossil fuels for renewable fuels (Čuček et al., 2012) or opting for more for less impactful raw materials (Kravanja and Čuček, 2013). The idea of indirect unburdening effects has been further applied and developed by scientists. Kravanja and Čuček (2013) have integrated unburdening effects into multi-objective optimization methods by introducing the relative total sustainability index that assesses the combined environmental, social and economic sustainability of a (product) system. How and Lam $(2017 ; 2018)$ have applied the unburdening effects in a principal component analysis to assess and optimize the sustainability performance of product systems.

Green marketing literature has identified that communicating the positive impacts of products and services is a challenge. To tackle credibility challenges, Ramirez et al. (2014) recommends more consistent communication of a sustainable product's economic benefits and positive environmental impacts. The research by Cronin et al. (2011) reinforces the perception that the communication of a product's environmental benefits is a delicate issue, as green marketing strategies have to avoid greenwashing while combating customer confusion and cynicism. Furthermore, sustainability-oriented customers can be a significant market for some companies (Patala et al., 2016). Access to this market requires rigorous demonstration and communication of expected sustainability benefits of product and service offerings. The need for communicating positive environmental impacts has been identified by researchers, e.g. by Pihkola et al. (2010), Tynkkynen, and Berninger (2017). Bjørn and Hauschild (2013) emphasize the need to introduce positive product attributes in LCA as well as the potential of developing LCA and eco-efficiency approaches towards being able to provide input for positive marketing and communication in the industry sector.

Several authors emphasize the need for changing the business mindset from being focused on reducing negative impacts to enhancing positive ones. Dyllick and Hockerts (2002) introduce this idea, while Young and Tilley (2006) and Dyllick and Muff (2016) explore the ideas of efficiency and effectiveness. Considering effectiveness, Dyllick and Muff (2016) discuss the creation of a "positive footprint" over the whole life cycle of a product, as a step forward in developing sustainable business, in contrast to merely pursuing efficiency, i.e. minimizing footprint (usually on a business economics basis). McDonough and Braungart (2002a) refer to the triple bottom line as a business approach that works to balance economic, ecological, and social sustainability goals with a focus on minimizing negative impacts. Furthermore, they suggest a new concept, triple top line, which is about identifying new business opportunities by creating positive beneficial impacts, or a "beneficial ecological footprint" (McDonough and Braungart, 2002a). Dyllick and Rost (2017) state that companies are more likely to consider their social impacts from a positive perspective, for example, the creation of jobs and the well-being of their employees, whereas they judge environmental impacts from a negative perspective. Dyllick and Rost (2017) move the sustainability discussion on from a company level to product level, stating that considering and optimizing the positive impacts of products (handprint) instead of focusing on minimizing their negative footprints is a step toward developing truly sustainable 
products. Regarding the sustainability assessment of products, Sala et al. (2013) conclude that life cycle-based methodologies should be broadened from avoiding negative impacts to also proactively enhancing positive impacts.

Whereas the 'footprint' concept is applied to refer to negative environmental impacts, 'handprint' is less well-known but can be used to refer to the positive impacts. This handprint concept was first launched in 2007 by UNESCO, when it was determined as a measure of Education for Sustainable Development action, aiming to decrease the human footprint (Handprint Action Toward Sustainability, n.d.). Biemer et al., (2013) and Norris (2015) have emphasized the environmental approach to handprinting. Whereas the concept of a footprint is approached by looking to reduce its effects close to zero, with a handprint there is no limit to the good that can be achieved (Biemer et al., 2013).

In the ongoing German Handprint project (Handabdruck), measurement, evaluation, and communication tools for the ecological, economic and social impacts of products are being created (Beckmann, 2017). They are pursuing an ambitious goal of taking into account all the three pillars of sustainability. In the scope of Handprint-Based NetPositive Assessment, both the environmental and social impacts of products and actions are addressed (Norris, 2013). In the previous methods the reduction in an organization's footprint is considered to be part of a Handprint. As Norris (2015) and Beckmann et al. (2017) include the reduction of one's own emissions e.g. in the production phase as one means to create handprint, it can be argued that this overlaps with reducing their own footprint. The handprint approaches of Biemer et al., (2013) and Norris (2015) emphasize the positive reinforcement loop of doing good. They accent that positive action promotes other positive actions, e.g. in terms of people educating each other regarding accrued knowledge. Although this is true in many cases, it is hard to prove and even harder to measure and allocate to someone's credit. Biemer et al., (2013) also include the possibility of creating handprints through buying carbon offsets.

Industries and companies have already recognized the need to communicate the environmental benefit of their products over others in the market. Industry sectors in chemistry (ICCA and WBCSD, 2013) as well as in ICT (GeSI, Global e-Sustainability Initiave) have advanced this issue from their own point of view. The chemical sector has introduced industry-related guidance (ICCA and WBCSD, 2013) with guidelines for calculating and reporting avoided emissions are compiled. Companies like Outotec (Outotec, 2015) have launched their own initiatives for handprints.

The handprint concept has emerged as a response to the demand for a method to quantify the positive impacts of a product. However, the handprint concept has been simultaneously developed by multiple researchers and industries. This uncoordinated development work has led to a multitude of definitions and scopes for the handprint concept, which requires consistent clarification. The differences in the existing handprint approaches call for harmonized guidelines for handprints to become an established means in company communication.

As the first objective, the article provides a universal definition to handprint that can be utilized in organizations' stakeholder communication and scientifically justified. Furthermore, this article specifically defines carbon handprint. As the second objective, the article defines the role of carbon handprint in the context of existing LCA-based methodologies. The article suggests how to utilize and combine the existing LCA viewpoints in a carbon handprint assessment. As the third objective, the article provides general guidelines for the LCA-based quantification of a carbon handprint of organizations' products.

The scope of the article is a carbon handprint, which refers to the greenhouse gas emission reduction a product can create. Only after achieving clear guidelines for one environmental impact category can we consider the methodology's applicability to other impacts. Thereby, our contribution differs from that of Beckmann (2017) and Norris (2013) whose handprints consider multiple environmental impacts and dimensions of sustainability. A further difference to these previous contributions is that we aim to clearly differentiate between handprints and footprints and avoid their overlapping. In contrast to Biemer et al. (2013) and Norris (2015) who emphasize the positive reinforcement loop of doing good, our starting point is the definition of a handprint concept for organizations to solidly calculate their product's effect in reducing greenhouse gases. Contrary to Biemer's et al. (2013) acceptance of buying carbon offsets, we construct the handprint concept based on the actual impacts of the products or services provided by the organization. By following this principle, the buyer of the product or service can ascertain that, by purchasing this specific product, a certain amount of greenhouse gas emissions can be reduced. The seller can also use the same argument as a selling point. 
This article is divided into three main parts: a presentation of the theoretical background of the carbon handprint approach proposed, a demonstration of its usage with actual case calculation, and finally an examination of the similarities and differences between the carbon handprint approach and other LCA based applications in the discussion section

\section{METHODS}

The development of the carbon handprint approach has been based on three different means. First, we have reviewed the existing research on assessing positive environmental impacts (e.g. Biemer, Dixon, and Blackburn, 2013; ICCA and WBCSD, 2013; Norris, 2015). We have also closely explored the guidance and standards given for carbon footprint calculation (ISO 14067, 2013; WBCSD and WRI, 2004) and LCA (ISO 14040, 2006; ISO 14044, 2006), because we aim to base the carbon handprint approach on the LCA guidelines approved by the scientific community as consistently as possible.

Secondly, we interviewed companies and associations about their expectations and preparedness on carbon handprinting. A total of 20 interviews were completed, including the manufacturing, ICT, chemical, construction, paper, food, recycling, and consulting sectors. The interviewed 14 companies included both SMEs and large international companies. The six associations interviewed represented NGOs and trade associations. The interviews comprehensively covered the range of life cycle aspects, from raw material processing and manufacturing to end-oflife. Experience of interviewees' environmental impact assessment varied from 'no experience at all' to 'several years of expertise.'

The majority of the respondents (ca. 75\%) had already used life cycle thinking, and the main purpose of LCA studies had been for communications and marketing purposes. Almost half of the respondents (9) had in some way calculated positive aspects, e.g. in terms of avoided emissions. The benefits of handprinting were seen as multifold, proving ideal for internal education or process management within the company. Handprints could also serve as a possible attraction for new customers, so incorporated into branding and/or marketing initiatives. Communicating the benefits of handprints was seen as very important, therefore, and companies should strive to make them easy and simple to understand.

Thirdly, as a greatest input to the methodology development, seven case studies were examined. The case studies were drafted based on the performances of different kinds of products, services, and processes, in order for the methodology development to benefit from a varied range of information. Therefore, it is possible to calculate handprints not only for products but also for services and technologies.

The chosen case studies were, 1) material for shopping bags from a material manufacturer 2) renewable diesel from a fuel manufacturer, 3) elevator technology from an elevator manufacturer, 4) an additive manufacturing service from a 3D printing company, 5) the cooling technology of a base station from a wireless network service provider, 6) a carpet service from a decoration company, and 7) a bio-waste treatment solution from a composter manufacturer. One case, the renewable diesel of Neste, is used in this article to demonstrate the course of handprint assessment.

Each solution was examined from the point of view of various customers, with value drivers being recognized for each customer. Both business-to-customer products as well as business-to-business products were examined. In order to ensure the applicability of the carbon handprint approach, the scope of the cases varied from consumer cases to both business and city-related cases, and the products chosen covered many different industrial sectors. In addition, the studied products represented both mass-produced products and also more tailor-made products for the specific

needs of a customer. The studied cases were also based on applicable situations, in which several actors in the value chain were found to influence the creation of a carbon handprint. 


\section{RESULTS}

\subsection{Determining a carbon handprint}

We define the handprint and carbon handprint as follows:

A handprint refers to the beneficial environmental impacts that organizations can achieve and communicate by providing products that reduce the footprints of customers.

A carbon handprint is the reduction of the carbon footprint of a customer or customers.

Organization can create a carbon handprint via several mechanisms, the possibilities of which Figure 1 simplifies. The organization can provide a raw material, a part, a component, a fuel, a technology, a process, a product or a service, here referred to as X (later on abbreviated as 'product') that can be shown to reduce the GHG emissions of another product system - here Y. Product system Y can represent the customer or the actor using the product or further processing or selling it. In the product system $\mathrm{Y}$, the product $\mathrm{X}$ can reduce the carbon footprint of $\mathrm{Y}$ by influencing in the following ways:

1) Material use: Replacing non-renewable/GHG intensive materials / Avoiding material use / Increasing material-use efficiency

2) Energy use: Replacing non-renewable/GHG intensive energy and fuels / Avoiding energy/fuel use / Increasing energy efficiency

3) Waste: Reducing waste and losses / Contributing to recycling, reuse, and remanufacture

4) Lifetime and Performance: Lengthening the lifetime of a product / Enabling the performance improvement of a product

5) Carbon capture and storage: Contributing to GHG sinks through land-use change / Removal of carbon into biomass / Storing of carbon into products

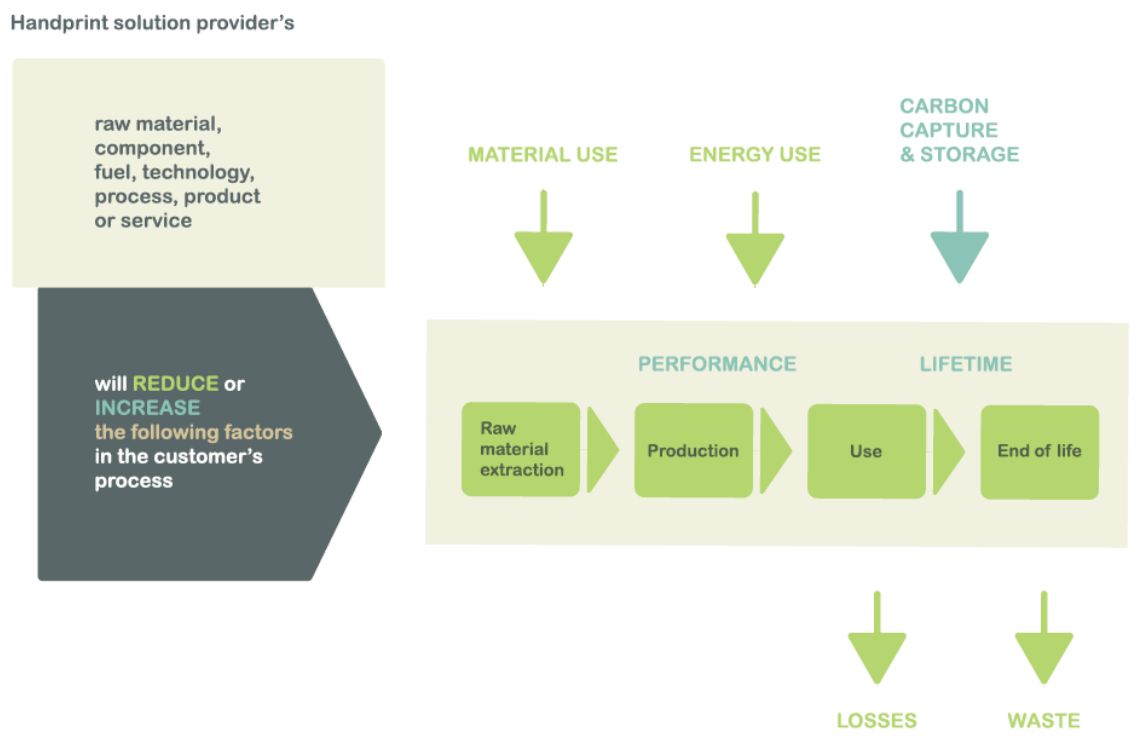

Figure 1. Mechanisms for a carbon handprint to be created by the handprint solution applied by a customer. The handprint solution could be able to reduce the factors written in green and increase the factors written in blue in the customer's process, resulting in GHG reduction. 
Calculating the carbon handprint for the organization's product $\mathrm{X}$ is achieved by simply comparing the carbon footprints of this modified practice to the baseline practice (see Figure 2). The carbon handprint is created if the carbon footprint of product system $\mathrm{Y}$ is smaller when using product $\mathrm{X}$ than it is by using baseline product $\mathrm{B}$.

$$
\text { Carbon handprint }_{X}=\text { Carbon }_{\text {footprint }} \text { Baseline practice }- \text { Carbon footprint }_{\text {Modified practice }}
$$

The carbon handprint is equal to the reduction of the carbon footprint of a customer, but the term 'handprint' is announced to the product of the organization that provides this solution. Thus, the product that enables the footprint reduction has a handprint.
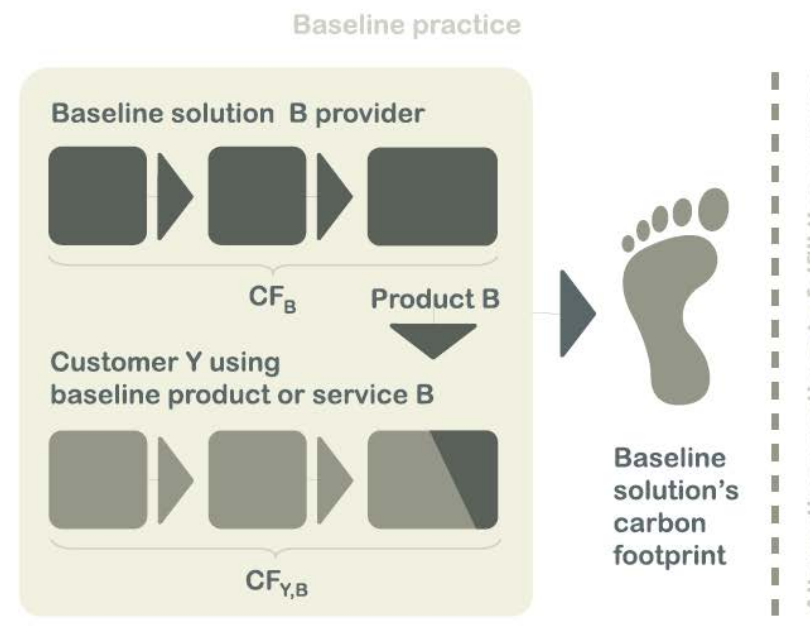

Modified practice

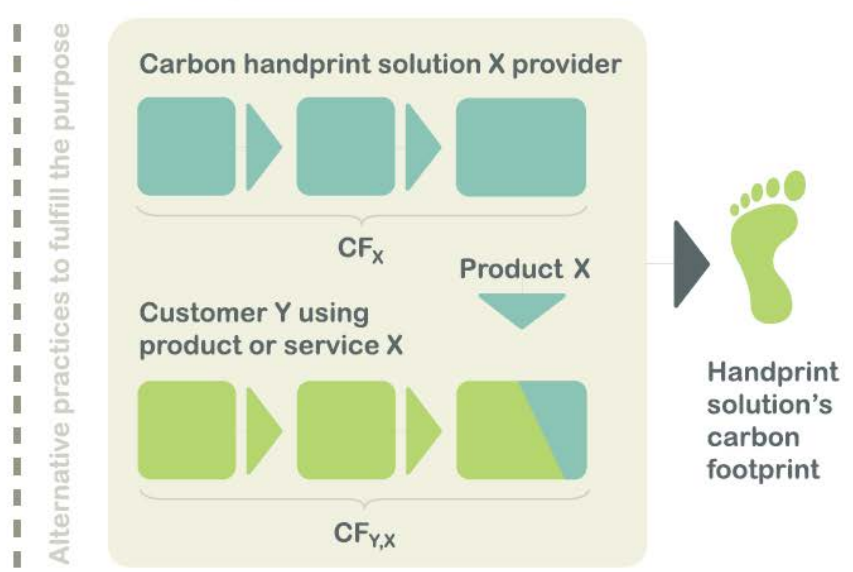

Difference between the carbon footprints of these two systems equals to the handprint of a product $\mathrm{X}$

Figure 2. Reduced carbon footprint is equal to the created carbon handprint

The carbon handprint can be created by two means, as presented in Figure 3, or with combinations of those two means. The GHG reduction, when compared to the baseline, can already occur in the processes of the carbon handprint solution provider (marked as $\mathrm{CF}_{\mathrm{X}}$ ), so long as they provide the solution with less GHG emissions than the baseline solution provider (marked with $\mathrm{CF}_{\mathrm{B}}$ ). This situation is described with the column on the left in Figure 3. Another basic option is that the carbon footprint of the customer's product (marked as $\mathrm{CF}_{\mathrm{Y}, \mathrm{X}}$ ) can be reduced with the help of the carbon handprint solution provider's product $X$. This situation is described with the column on the right in Figure 3. An example of this could be a food packaging, which helps to save the food better and so prevents food waste and causes less GHG emissions, accordingly. As discussed, combinations of these two means can also result in a carbon handprint. One section $\left(\mathrm{CF}_{\mathrm{X}}\right.$ or $\left.\mathrm{CF}_{\mathrm{Y}, \mathrm{X}}\right)$ can also be allowed to increase when compared to the corresponding section in the baseline, but the total carbon footprint should be lower than the baseline's footprint in order to create a carbon handprint. 


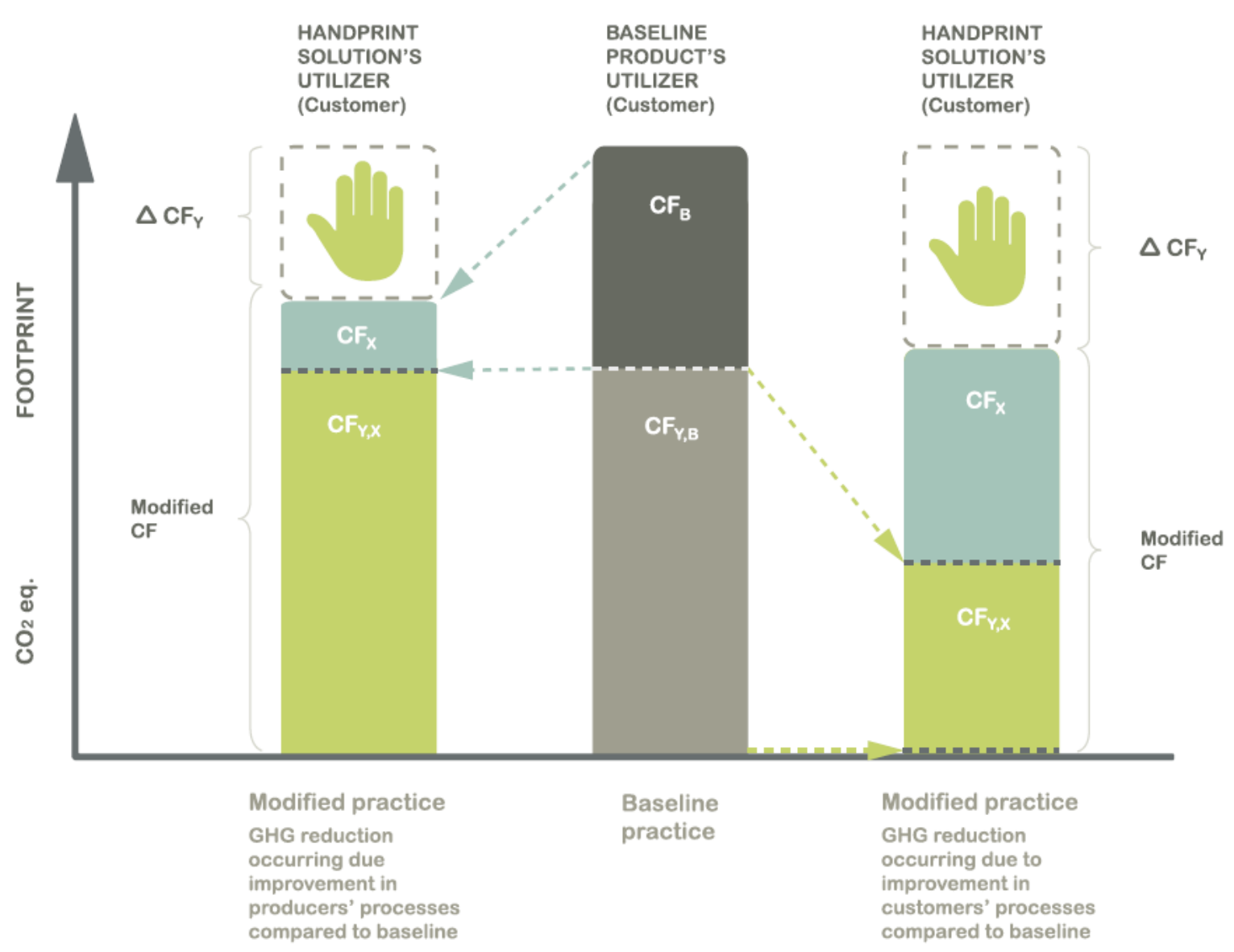

Figure 3. Two basic means for a carbon handprint to be created by the reduction of carbon footprints (CF)

We suggest to clearly differentiate the improvements undertaken within an organization's own production system as reductions of one's footprint. Reducing one's own footprint alone is not creating a handprint. Handprint is an indication of the total footprint of a product when used by a (potential) customer. Companies with a poor environmental performance currently have great potential for achieving reductions in their own footprint. This is still not yet a handprint, but a necessity to be prioritized first in order to deserve a place in the market and have a license to operate. At the same time, forerunner companies have already improved their performance to the top class of resource-efficient and sustainable actors. There is less and less room for improvement in their own functions (reduction of one's own footprint) but plenty of options to help others to reduce their footprints (handprint).

A carbon handprint functions as a marketing and communication tool. For a customer, the possibility of reducing their footprint can prove to be a considerable sales argument. A carbon handprint also offers a means for identifying whether there is a need to further develop one's product in order to create a handprint. A handprint assessment might reveal that the difference in resulting carbon footprints is minimal when compared to a baseline product, or even that the baseline product might have a smaller footprint. 


\subsection{Steps in the carbon handprint calculation}

As guidance for the carbon handprint calculation, a step-by-step procedure is presented (see Figure 4). As a general rule, it can be noted that, as with LCA in general, a handprint calculation is also an iterative process. Due to findings in the analyses of subsequent steps, it might be necessary to update the prior steps.

\begin{tabular}{|c|c|}
\hline $\begin{array}{l}\text { CARBON HANDPRINT } \\
\text { METHODOLOGY }\end{array}$ & -SUB-QUESTIONS \\
\hline $\begin{array}{l}\text { 1. Choosing the product for } \\
\text { handprint calculation }\end{array}$ & -What is the product that potentially has a carbon handprint? \\
\hline $\begin{array}{l}\text { 2. Defining customer(s) for the } \\
\text { product }\end{array}$ & -Who are the key customers the company wishes to influence? \\
\hline 3. Defining the aim & - By what means can the product or service influence the customer's GHG emissions? \\
\hline 4. Defining the baseline & $\begin{array}{l}\text {-What is the relevant baseline for comparing the modified practice within the identified market } \\
\text { area and timeframe? }\end{array}$ \\
\hline 5. Defining the functional unit & $\begin{array}{l}\text { - What is the most descriptive functional unit that describes the purpose of the product for each } \\
\text { customer? }\end{array}$ \\
\hline $\begin{array}{l}\text { 6. Defining the unit for clear } \\
\text { communication of results }\end{array}$ & $\begin{array}{l}\text { - What is the most descriptive unit that can also be easily communicated to each type of } \\
\text { customer? }\end{array}$ \\
\hline 7. Defining system boundaries & $\begin{array}{l}\text {-What lifecycle stages are included and what stages can be excluded on the basis that: } \\
\text {-A) there is no difference between the baseline and the modified practice, and } \\
\text {-B) the carbon handprint product influences only parts of the lifecycle of the customer's } \\
\text { product? }\end{array}$ \\
\hline $\begin{array}{l}\text { 8. Defining data needs and } \\
\text { sources }\end{array}$ & $\begin{array}{l}\text {-What kind of data is needed that is representative and accessible: } \\
\text {-A) when the actual customer is known? } \\
\text {-B) when the exact customer cannot be determined? }\end{array}$ \\
\hline 9. Calculating footprints & -What are the footprints of the baseline and modified practice? \\
\hline 10. Calculating the handprint & -What is the difference between the footprints of the baseline and the modified practice? \\
\hline
\end{tabular}

Figure 4. Ten steps and assisting sub-questions in the carbon handprint approach

\subsubsection{Choosing a product for handprint calculation}

The first step for a company that is considering conducting a carbon handprint calculation is to decide on the product that will be subject to assessment. The hypothesis should be that the product has the potential for reducing GHG emissions when it is utilized by a customer. As a basis for the selection of the product for handprint calculations Figure 1 , introducing five possible ways to reduce a carbon footprint, can be used. The company can make a preliminary screening of their products to assess which of them might provide carbon footprint reductions in their customer's processes. One possible way to execute the screening is to gather an expert panel that is well acquainted with the company's products and go through the five possible carbon footprint reduction pathways. Whether the chosen product(s) truly have GHG emission reduction possibilities will be further defined in subsequent steps.

\subsubsection{Defining customers}

In order for the carbon handprint to be created, the product needs to have a potential user, now referred to as a customer. A single product may have different kinds of users that utilize the product for different purposes. These varying circumstances need to be understood so that the routes different customers take will ultimately inform the 
carbon handprint calculation. When studying the customer whose carbon footprint is reduced, it is important to focus on the life cycle stages where the benefit truly originates, as this directly relates to the implementation decision and so leads to the usage of the carbon handprint product.

\subsubsection{Defining the aim}

The mechanisms for forming the carbon handprint can vary, as presented in Figure 1. The anticipated carbon handprint forming mechanism can be estimated, but its actual relevance will only be discovered after the assessment is conducted.

\subsubsection{Defining the baseline}

Fourthly, in order to quantify the amount of reduced GHG emissions, it is essential to determine the baseline situation as a point of comparison. The baseline refers to the alternative or current solution in place that delivers the same functions to the customer as the handprint solution. Inspired by the principles presented in the guidelines of ICCA and WBCSD (2013), we have constructed our own proposition:

The baseline and the handprint solution shall both:

- $\quad$ Deliver the same function

- Be used for the same purpose

- Be available in the market and used in the defined time period and geographic region

- Be assessed in a consistent manner (in terms of data quality, representativeness, system boundaries, assumptions, etc.)

Contrary to the carbon footprint, which represents the absolute sum of GHG emissions and removals in a product system (expressed as $\mathrm{CO}_{2}$ equivalents) the carbon handprint refers to a change that will result in a beneficial climate impact. In order to assess the change, we need to determine a baseline against which the new situation is compared. It is easy to understand that the selection of the baseline has a major impact on the handprint result as, by choosing the "worst possible" baseline with a poor environmental performance, it is possible to increase the handprint significantly. Therefore, the determination of the baseline must be well justified.

Two fundamental questions affect the baseline. The first is whether the product that presumably creates a handprint is replacing another product or is new to the market. If the product is new, the comparison will be made between the situation with and without it. Instead, if the product replaces another product, this will lead to the second fundamental question: is the targeted application company specific? When the customer using the product is known, the baseline, i.e. the current product to be replaced, can be identified precisely. However, if the product is released to the market with a range of potential customers and uses in mind, the number of baselines becomes under consideration. However, if a clear market leader can be recognized, this should be used as a baseline. For example, the introduction of a shopping bag made of new raw material will clearly replace the currently used plastic bags in shops. However, sometimes it is not possible to identify one type of product from the market as the obvious replaceable product. For example, the environmental performance of currently-used traffic fuels shows a great variation. If you introduce a new type of fuel, it is impossible to state the exact fuel type it will replace. In this case, the average should be taken from all options and used as the baseline. The third option is to use the available product specifications, standards or BAT-specifications as baselines. This would be justified in cases where the business-as-usual technologies are plentiful and the data of the competitors hard to attain. The baseline situation may also be a combination of multiple baseline products to be replaced if the handprint solution is a multi-functional product. 
The baseline determination procedure:

1. Is the product new on the market?

a. YES $\rightarrow$ Use the situation without the product as the baseline

b. $\mathrm{NO} \rightarrow$ Go to the question 2

2. Can the customer be specified?

a. YES $\rightarrow$ Use the customer's current product or another option available on the market as the baseline (not the previous generation product of the handprint provider)

b. NO $\rightarrow$ Choose one of the following as the baseline:

i. Market leader or typical product in the identified reference area and time

ii. Average product in the identified reference area and time

iii. Product specification or BAT (best available technology) that determines the available options

\subsubsection{Defining the functional unit}

The functional unit is highly dependent on the customer and the purpose the customer uses the product for. . The functional unit should be defined based on the needs fulfilled by the product during its life time. The functional unit should represent the use pattern or profile of the customer the calculation is done for.

\subsubsection{Defining the unit for clear communication of results}

From a customer's perspective, a handprint is the potential for greenhouse gas savings that a product can deliver for them. As climate impacts are in focus, the unit of a handprint is by default carbon dioxide equivalents. However, the $\mathrm{CO}_{2}$-eq. amount can be announced in reference to a unit that is more representative to the use of that product in hands of specific customer.

\subsubsection{Defining system boundaries}

The system boundaries shall be provided with a flow diagram presenting the life cycles of the compared solutions. All activities from cradle to grave should be considered, following the system boundary principles set in ISO 14040-44 and ISO 14067. As handprint results are intended to support decision-making related to a potential change in the examined product system, the differences between the two systems are in focus. In the carbon handprint approach, the definition of system boundaries depends on the aim of the study, as well as the customer in question (cf. Zamagni et al., 2012). Fundamentally, all carbon handprint studies include research questions regarding a mechanism by which the product can influence the customer's GHG emissions, as well as how much a potential carbon handprint solution can decrease the carbon footprint of customers. Therefore, the life cycle stage where the benefit for the customer occurs has to be within the system boundaries.

In cases where there are identical life cycle stages or parts or processes in the life cycle of compared alternatives, these can be excluded from the study. A typical situation that demonstrates this is where the manufacturer's product only affects some parts of the life cycle of the customer's product. The rest of the life cycle stages can, therefore, be excluded, as there is no difference to them, whether baseline practice or modified practice is used (cf. Zamagni et al., 2012). The time horizon in determining consequences further defines processes to be included or excluded (Weidema et al., 1999; Zamagni et al., 2012). Scenario modeling and sensitivity analyses may be necessary (Zamagni et al., 2012). In situations where some parts of the life cycle are chosen to be excluded, there needs to be transparency on which parts and why.

\subsubsection{Defining data needs and sources}

Before the actual calculations, data needs need to be identified. In carbon handprinting, there are two types of premises: the actual customer is known, or the customer cannot be determined but the organization knows potential customers or customer groups. Naturally, in the latter case, information cannot be gathered as in the first case, but assumptions need to be made. 
If the customer can be specified, one should use the recorded primary data from previous years. Often, organizations keep records of the activities of past years and, if so, the most recent information can be utilized. One calendar year is the recommended length of time to collect the data from. In case of varying annual data, one should use an average of multiple years' data. It has to be noted that the data for the baseline practice and modified practice require the same timeframe.

In many cases where the customer is a consumer, one has to rely on statistical or average data, as the uncertainty increases when dealing with a vast number of consumers with different operating patterns. This is especially true with the use of mass-produced products.

The data used should be representative in terms of geographical, time-related, and technological coverage, as well as being precise and complete, as determined in ISO 14044 (2006).

\subsubsection{Calculating footprints}

The ninth step is for calculating the carbon footprints of the systems in comparison, following the standardized LCA methodology. It is recommended to use carbon footprint calculations made in accordance with ISO 14067, as this methodology is strongly based on ISO 14040 and ISO 14044.

\subsubsection{Calculating handprint}

Finally, the carbon footprints of the two systems are compared. If the carbon footprint of the modified practice is smaller than the carbon footprint of the practice using the baseline solution, then a carbon handprint has been created. The quantity of the carbon handprint is the difference between these two carbon footprints, as $\mathrm{kg} \mathrm{CO}_{2}$ eq (see Figure 3). One should note that the carbon handprint is strongly related to changes in circumstances and will take place after the handprint provider's solution has been applied by the potential customer. Furthermore, the carbon handprint is bound to a specific timeframe, whereas the baseline keeps moving over the years as more sophisticated solutions come to occupy the market. The handprint is valid as long as the data used for the calculation is representative for the examined situation.

\subsection{Demonstration}

The applicability of the carbon handprint approach was tested using seven different case studies. In the following, the process of carbon handprint calculation is demonstrated with one of the cases: Neste renewable diesel (RD). Simultaneously, this example acts as a validation of the approach. The framework for Neste's RD carbon handprint calculation for different kinds of customers is presented in Figure 5, then explained step by step in the following section. 
CARBON HANDPRINT METHODOLOGY

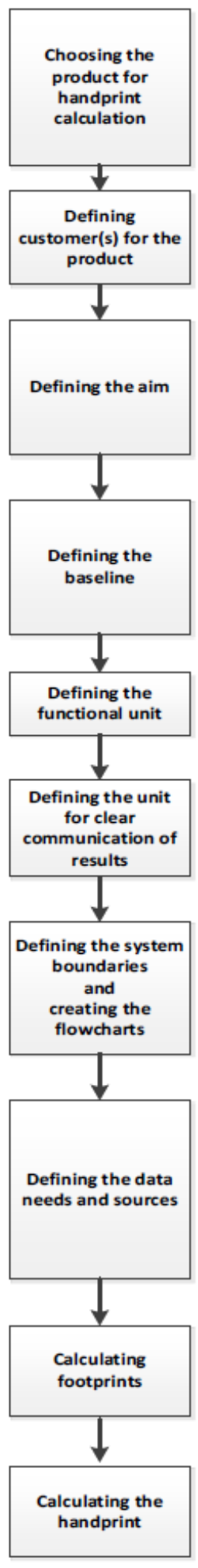

\section{Case Neste}

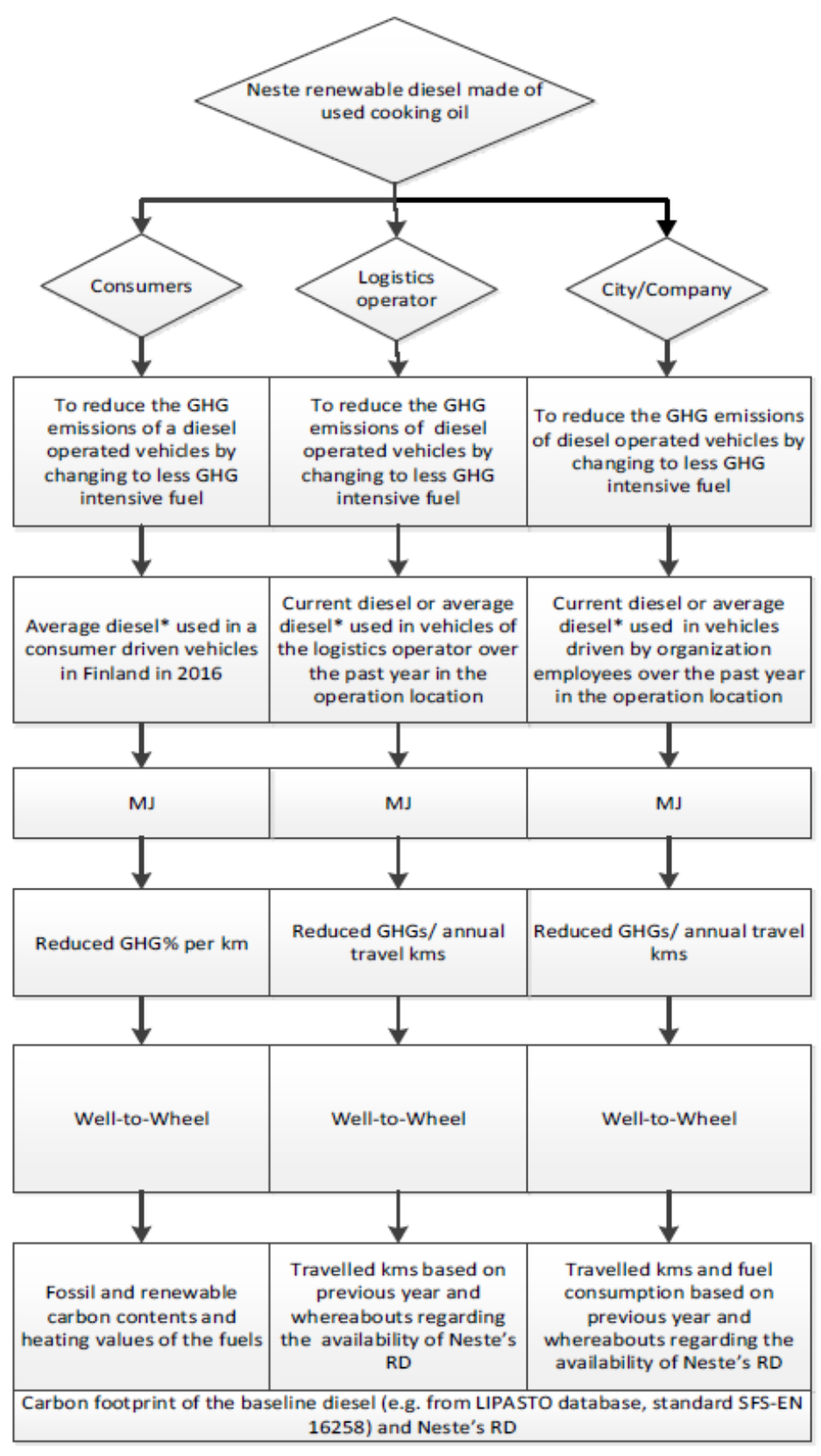

*Average diesel: average diesel fuel sold and used in Finland in 2016

Figure 5. Carbon handprint framework demonstrated with Neste case 


\subsubsection{Choosing a product for Neste’s handprint calculation}

The preliminary assumption is that the hydrotreated vegetable oil (HVO), produced from used cooking oil (UCO) has the potential to reduce the greenhouse gas emissions of the customer using the fuel.

\subsubsection{Defining customers for renewable diesel}

Three different types of customers are identified: 1) consumers using the fuel (private car owners), 2) logistic operators, 3) cities or companies. The customers are identified based on the function and purpose of the product. The function of the renewable diesel (RD) is to act as a motive power for diesel-operated vehicles. Consumers consist of all customers using fuel for their own purposes. For logistics operators, the purpose is to move objects from place to place. Whereas for cities and other companies, the purpose is to provide their employees with a means to travel. Thus, cities and companies can be seen as one customer type.

\subsubsection{Defining the aim of RD}

Consumers, logistics operators, cities, and companies have the potential to reduce their traffic-related GHG emissions with $\mathrm{RD}$, which originates from renewable and waste sources, specifically now from used cooking oil. The aim is to determine the reduction potential of GHG emissions if customers choose to use RD as compared to their current practices.

\subsubsection{Defining the baseline for $\mathrm{RD}$}

RD has to be compared to fuel(s) that provide(s) motive power for diesel engines. The market area was chosen to be Finland. Therefore, the baseline fuel needs to represent recent and valid information related to sold and used diesel fuels in the Finnish market. When consumers are considered as customers, the possibilities of choosing the fuel are vast, and cannot be exactly specified. If the comparison was only made with fossil fuels, it would be misleading as, in Finland, the share of biofuels is already high. Therefore, the baseline fuel is determined as the average diesel fuel sold and used in Finland in 2016, including fossil diesel and 12\% of bio-based diesel (LIPASTO, 2017). The annual reports of specific market areas reflecting the fuel usage are well-suited to be used as a baseline.

In the case of logistics operators, cities and other companies that can be specified, the baseline fuel could be defined more accurately, and the current diesel in use could be chosen as the baseline fuel.

\subsubsection{Defining the functional unit for diesels}

If the aim of the carbon handprint is to show how a logistic provider's carbon footprint can be reduced by means of the product, the number of kilometers driven in a previous year by the diesel cars owned by a company can serve as a functional unit. In order to express the emissions produced in fuel processing and transportation stages, as well as in a use stage, the amount of fuel needed to achieve that number of kilometers needs to be known. However, using weight or volume as a reference flow could be misleading, because there may be differences in the performance of a motor, in densities, in energy contents or in the carbon content of a fuel (e.g. Pexa et al., 2015) which may have an indirect impact on emissions. Therefore, as the volume of the fuel can usually be taken from the bookkeeping of a logistics company, it should be transformed to megajoules. This choice is also supported by the fact that the emissions of greenhouse gas emissions, produced in a well-to-wheel life cycle, can be found from a database expressed per megajoules of fuel energy.

\subsubsection{Defining the unit communicating RD handprint results}

Characteristics of different customers and equity of different products should be considered when defining the units communicating the results. If GHG reduction per liters or weight is used as a unit, communication with consumers is not equivalent for all compared solutions. $\mathrm{MJ}$ is seen as an unconventional unit because it does not tell the purpose of a fuel for customers. Instead, using GHG reduction per $\mathrm{km}$ can be seen as relevant information, when consumers are comparing alternatives according to performance and the GHG emissions of a fuel. In the case of logistics operators, cities and companies, the customer is most likely interested to know the annual reduction potential of GHG emissions 
that RD can offer. Thus, the annual reduction of GHG according to annually driven kilometers can be used in communication.

\subsubsection{Defining system boundaries for renewable and baseline diesel}

In this case, the fuel is burnt in the motor of a vehicle and, thus, the product systems of fuels and vehicles are considered as part of the system boundary. It is assumed that different fuels do not decrease or reduce the lifetime or efficiency of a motor. Thus, the life cycle stages of vehicles considered to be other than the use phase can be excluded. The system boundary fits in the definition of Well-to-Wheel (W-to-W) approach, as presented in Figure 6.

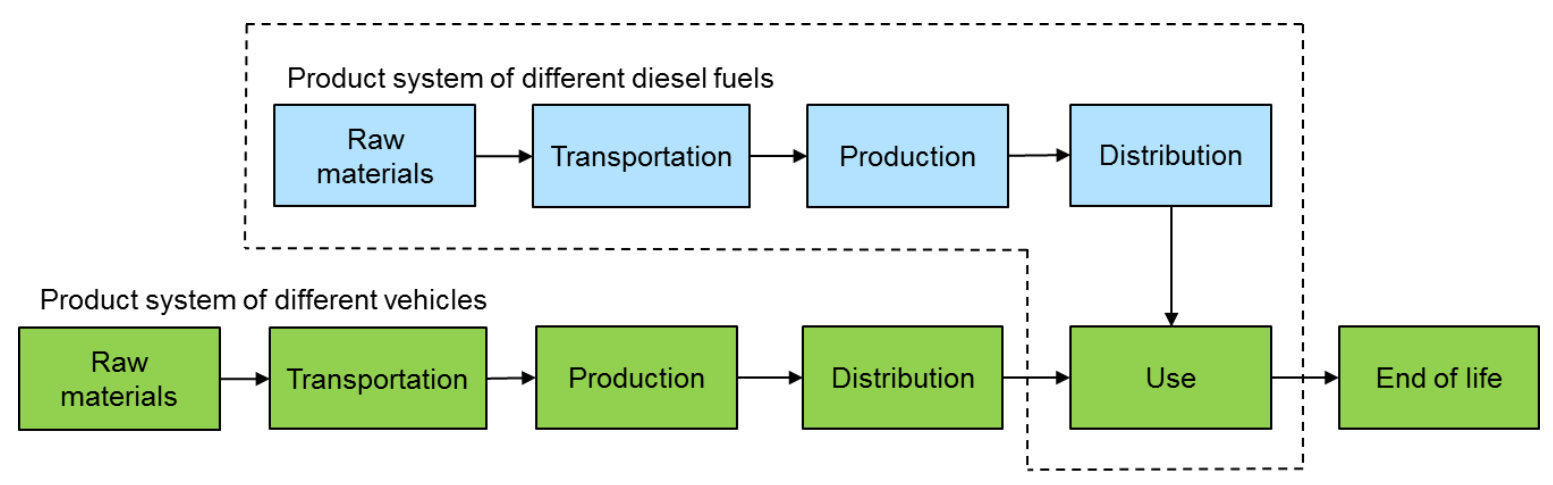

Figure 6. System boundaries

3.3.8 Defining data needs and sources in case of diesel

To calculate the baseline, the GHG emissions of different used fuels have to be known. This can only be achieved if the volumes of fuels are known, including their lower heating values, densities, fossil and renewable carbon contents, and their emissions caused by the production system. However, that kind of information is not publically available in Finland. Another option is to use the average emissions of the used diesel fuels. VTT keeps the public database LIPASTO, which estimates the annual emissions of traffic-based fuels in Finland. The emission figures are calculated according to the standard 16258, with diesel emissions including the life cycle stages of a well-to-wheel approach (SFS-EN 16258, 2012).

As for logistics operators, cities, and other companies, they commonly have well-kept databases regarding their vehicles' annually driven distances and fuel consumptions. The annual information accrued can be used as primary data. If there is no available data on the characteristics of the used fuel, then the average fuel is used as a baseline.

\subsubsection{Calculating the footprints of compared fuels}

The carbon footprint of studied RD is calculated according to the ISO 14067 standard. As the studied market area is Finland and part of the European Union, the directives and regulations determining the GHG emissions of different fuels (e.g. 2015/1513/EC, 2009/28/EC, 2009/1069/EC, SFS-EN 16258) are followed when defining the baselines and calculating footprints. Directive 2009/28/EC recommends using energy-based allocation whenever fuel emissions are studied. This directive assumes that waste and residue-based raw materials have zero life cycle greenhouse gas emissions up to the process of collection of those materials. In this case, the biogenic carbon intake equals the number of biogenic carbon emissions, resulting in zero net biogenic $\mathrm{CO}_{2}$ emissions.

Key data regarding the life cycle stages of RD are described and illustrated in Figure 7. The approximated distance that the used raw material - used cooking oil - has to be transported is $200 \mathrm{~km}$, transported by truck to the refinery located in Rotterdam, the Netherlands. It is assumed that fifty percent of the raw material is refined in Rotterdam and the other half is refined in Porvoo, in Finland. The raw material is then transported from Rotterdam to Porvoo by sea. The distance is approximately 1,750 km. The refineries of Rotterdam and Porvoo use the same processes, but the electricity and steam production has been assessed as state-specific. Actual input-output data from the HVO process 
of Neste has been used in the calculation, but it is largely confidential. Per 1,000 kg of UCO the net electricity consumption is $260 \mathrm{MJ}$ and the net steam consumption is 1,250 MJ. The byproducts of the processes are gasoline and propane, and their lower heating values are $43 \mathrm{MJ} / \mathrm{kg}$ and $46 \mathrm{MJ} / \mathrm{kg}$, respectively. (Neste, 2017, personal communications.) The diesel is distributed from the Porvoo refinery to its filling stations. Calculations assumed a distance of 100 kilometers traveled by Euro 6 trucks.

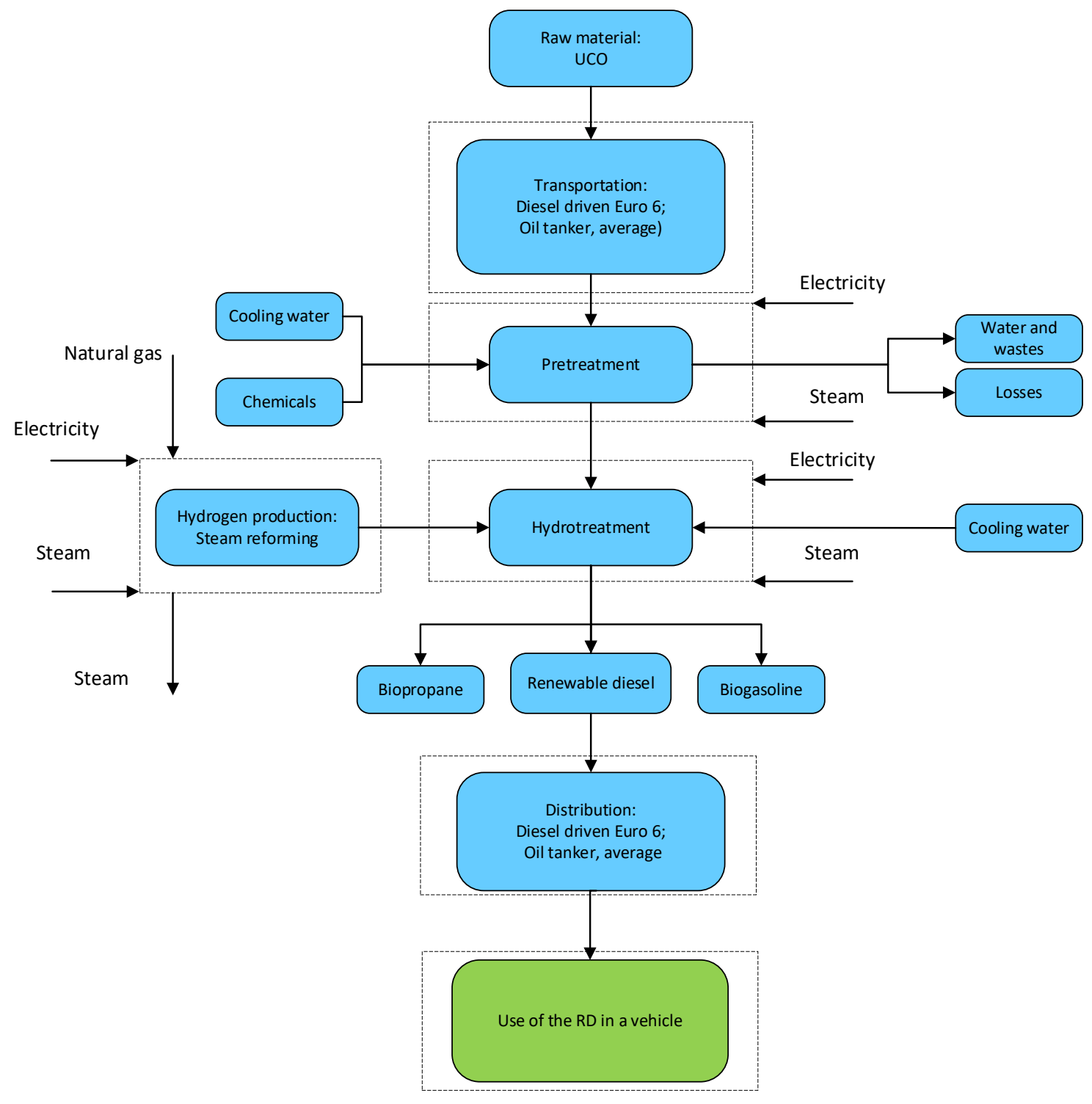

Figure 7. Flowchart for Neste's RD originating from UCO with material and energy flows

This calculation is made using a CML 2001 GWP (global warming potential) 100 year impact analysis method. Using $1,000 \mathrm{~kg}$ of UCO as raw material to produce and distribute RD causes global warming potential of $400 \mathrm{~kg}$ $\mathrm{CO}_{2}$-equivalents. When the energy allocation is used, because of formed valuable byproducts, the emission is 10 $\mathrm{gCO}_{2}$-equivalent/MJ. 


\subsubsection{Calculating the handprint of Neste’s renewable diesel}

For the baseline fuel, the GHG emissions within the system boundary can be derived from the standard SFS-EN 16258. According to this standard, the average GHG emission of the baseline fuel caused $86 \mathrm{~g} \mathrm{CO}_{2}$-equivalent per MJ in 2016, when the share of biofuel was 12\% (LIPASTO, 2017).

The handprint calculation is performed for just one vehicle owned by a logistics company. Only one vehicle is studied, for exemplary purposes. The examined vehicle operates in the Helsinki region of Finland, consuming 6 liters of diesel per $100 \mathrm{~km}$ and the annual driven $\mathrm{kms}$ in 2016 were 130,000 km. The logistics operator does not have information regarding the GHG emissions of the used fuel in 2016. Thus, the GHG emissions of average diesel are used as a baseline instead. When knowing the density $\left(0.824 \mathrm{~kg} / \mathrm{m}^{3}\right)$, the lower heating value $(43 \mathrm{MJ} / \mathrm{kg})$, and the emissions per liter of baseline diesel (SFS-EN 16258, 2012; LIPASTO, 2017), the consumed energy and total emissions per year can be estimated. Based on given values, 6 liters of baseline diesel per $100 \mathrm{~km}$ accounts for $2.1 \mathrm{MJ}$ per km.

$\mathrm{RD}$ is seen to be nearly proportional to the volumetric heating value and, in some cases, might slightly improve engine efficiency, when compared to fossil diesel (e.g. Bortel et al., 2017; Hartikka et al., 2012; Sugiyama et al., 2012). Thus, assuming that performances of the motors are the same, when baseline diesel and RD are combusted, is reasonable. This assumption means that the energy content of the fuel determines the consumed fuel per driven $\mathrm{km}$.

In addition to the performance of $\mathrm{RD}$, the availability of the fuel also has to be taken into account when calculating carbon handprint. It is also estimated that the distance to the nearest gas station selling RD is approximately $10 \mathrm{~km}$ longer when compared to the usual station. Considering the tank size of the examined vehicle (50 l), traveled annual distance, and the roundtrip to the nearest station selling $\mathrm{RD}$, the logistics operator has to refill the tank more often compared to the situation in 2016. Annually, based on the increased filling times and the location of the new station, the traveled distance increases by approximately $3,200 \mathrm{~km}$.

Now the carbon handprint can be calculated using the following equation, where $\mathrm{CH}$ is the carbon handprint ( $\left.\mathrm{t}_{\mathrm{CO} 2}-\mathrm{eq}\right)$, E refers to the required energy content of the fuel per traveled distance ( $\mathrm{MJ} / \mathrm{km})$, GHG refers to $\mathrm{W}$-to-W emissions per energy (gco2-eq $/ \mathrm{MJ}$ ), s refers to distance traveled $(\mathrm{km})$, and footnotes $\mathrm{RD}$ and $\mathrm{B}$ refer to renewable diesel and to baseline diesel:

$$
\begin{aligned}
& C H=E_{B} * G H G_{B} * S_{B}-E_{R D} * G H G_{R D} * S_{R D} \\
& =2.1 \frac{\mathrm{MJ}}{\mathrm{km}} * 86 \frac{\mathrm{g}_{\mathrm{CO}_{2-\mathrm{eq}}}}{M J} * 130000 \mathrm{~km}-2.1 \frac{\mathrm{MJ}}{\mathrm{km}} * 10 \frac{\mathrm{g} \mathrm{CO}_{2}-e q}{M J} * 133200 \mathrm{~km} \\
& =21 t_{\mathrm{CO}_{2}-e q}
\end{aligned}
$$

The logistics operator could save $21 \mathrm{t} \mathrm{CO}_{2}$ equivalents annually if they were to change their vehicle fuel to renewable diesel made of used cooking oil from the average diesel. The impact of this would multiply if the logistics operator had a fleet in the same region and the all vehicles changed the fuel in use. 


\section{DISCUSSION}

Above, a case study of renewable diesel was presented to demonstrate the steps of carbon handprinting. It is critical to remember, however, that the handprint result is linked to a specific customer; in this case, a logistics operator who drives a certain number of kilometers each year using renewable diesel instead of baseline fuel. This handprint can be thus used in communicating the carbon footprint reduction potential the renewable diesel can produce for this specific customer.

In general, carbon handprinting offers companies two major benefits over carbon footprinting. The handprint approach forces companies to extend their environmental responsibility beyond their gates. It urges them to customize their product to fit the needs and preferences of each customer and to optimize the product to the real-world operating environment in terms of $\mathrm{CO}_{2}$ emissions. It shifts the business mindset from mass-produced products to locallysustainable products, contributing to closed-loop product systems (McDonough and Braungart, 2002b) that are important for enhancing a circular economy. Simultaneously, the handprint approach gives companies the means to quantify the environmental benefits that their product offers to their customers. Previously, these kinds of calculation guidelines have been missing to verify the environmental benefits of products. Secondly, carbon handprinting offers the companies a tool for managing their climate impacts. This approach has its roots in the measuring of footprints, but instead of stopping there it requires the conductor to place the product being assessed in the surrounding environment, in the actual use of their customers, in a consistent way. This approach might not only reveal the climate benefits of a product but also the possibility that no handprint is created, which can be found out when compar to the baseline product in the same market. If so, this will provide a clear indication to the company to rethink their product and to optimize its carbon footprint throughout its life cycle. Handprint thinking is shifting the decision-making process from conventional towards a strategic decision-making process, where the long-term objective is to produce and use climate friendly solutions. The positive mindset of the approach emphasizes that actors involved are solving the challenge instead of just causing more greenhouse gas emissions.

In comparison to previously published methods for the assessment of environmental benefits of product systems, the carbon handprint approach has its own specific features. The idea of total indirect environmental footprint (unburdening effects), introduced by Čuček et al. (2012), is somewhat comparable to the idea of carbon handprint. However, in contrast to the handprint approach, according to Kravanja and Čuček (2013) the methods that consider the total environmental effects (and further total sustainability effects) as a sum of direct burdening and indirect unburdening effects lack geographic specificity and do not determine criteria for selecting the baseline, the "substituted system". Furthermore, the total indirect environmental footprint (Čuček et al., 2012) and its applications allow for the scientific assessment of the total environmental effects from a consequential perspective in general. Whereas, the handprint approach is further operationalized to company needs in communication to specific customers or customer segments.

As the second objective, the article defines the role of carbon handprint in the context of existing LCA-based methodologies. The article suggests how to utilize and combine the existing LCA viewpoints in a carbon handprint assessment. In order to further clarify the similarities and differences between the carbon handprint approach and other life cycle based applications, Table 1 is presented. Two main modelling principles, attributional LCA (ALCA) and consequential LCA (CLCA), as well as carbon footprint are included in the table. Understanding the differences between ALCA and CLCA continues to be debated in the LCA community (Hauschild et al., 2018). However, the purpose of the table is to illustrate the novelty of the handprint approach. 
Table 1. Main features of carbon handprint and other LCA approaches

\begin{tabular}{|c|c|c|c|c|}
\hline & ALCA & CLCA & Carbon footprint & Carbon handprint \\
\hline Main purpose & $\begin{array}{l}\text { Assessing potential } \\
\text { environmental } \\
\text { impacts of an } \\
\text { existing product } \\
\text { system (UNEP and } \\
\text { SETAC, 2011). }\end{array}$ & $\begin{array}{l}\text { Assessing the potential } \\
\text { environmental impact of a } \\
\text { change occurring in a } \\
\text { product system (UNEP and } \\
\text { SETAC, 2011). }\end{array}$ & $\begin{array}{l}\text { Assessing greenhouse gas emissions } \\
\text { and removals in a product system } \\
\text { (ISO 14067, 2018). }\end{array}$ & $\begin{array}{l}\text { Assessing positive greenhouse gas } \\
\text { impacts of a product/solution } \\
\text { applied by a (potential) customer. }\end{array}$ \\
\hline $\begin{array}{l}\text { Environmental } \\
\text { impact } \\
\text { categories }\end{array}$ & \multicolumn{2}{|c|}{ Several impact categories, incl. climate change } & \multicolumn{2}{|c|}{ Climate change } \\
\hline Added value & \multicolumn{2}{|c|}{$\begin{array}{l}\text { Identifying opportunities to improve the } \\
\text { environmental performance of products; informing } \\
\text { decision-makers in industry, government or non- } \\
\text { government organizations; the selection of } \\
\text { relevant indicators of environmental performance, } \\
\text { including measurement techniques; marketing (ISO } \\
\text { 14040, 2006). }\end{array}$} & $\begin{array}{l}\text { Added value of LCA applies with } \\
\text { climate change as a single impact } \\
\text { category. Beneficiaries are } \\
\text { organizations, governments, industry, } \\
\text { service providers, communities and } \\
\text { other interested parties (ISO 14067, } \\
\text { 2018) }\end{array}$ & $\begin{array}{l}\text { Added value of carbon footprint } \\
\text { applies. Identifying positive climate } \\
\text { impacts and opportunities to } \\
\text { improve the climate performance } \\
\text { of products/solutions; informing } \\
\text { decision-makers in industry and } \\
\text { organizations; marketing and } \\
\text { communicating positive climate } \\
\text { impact. }\end{array}$ \\
\hline $\begin{array}{l}\text { Intended } \\
\text { audience }\end{array}$ & \multicolumn{3}{|c|}{ Can differ and is closely linked to the intention of each assessment conducted. } & $\begin{array}{l}\text { (Potential) customer - either a } \\
\text { company (B2B), a consumer (B2C), } \\
\text { or another interested party. }\end{array}$ \\
\hline $\begin{array}{l}\text { System } \\
\text { boundary }\end{array}$ & $\begin{array}{l}\text { System boundaries } \\
\text { typically include the } \\
\text { life cycle of the } \\
\text { product with current } \\
\text { or potential } \\
\text { suppliers and } \\
\text { customers } \\
\text { (Weidema, 2003). }\end{array}$ & $\begin{array}{l}\text { System boundaries ideally } \\
\text { include all activities within } \\
\text { and outside the life cycle } \\
\text { that are of consequence of } \\
\text { a change being examined } \\
\text { (Ekvall and Weidema, } \\
\text { 2004). }\end{array}$ & $\begin{array}{l}\text { Quantification shall include all GHG } \\
\text { emissions and removals of those unit } \\
\text { processes that are part of the product } \\
\text { system that have the potential to } \\
\text { make a significant contribution to the } \\
\text { CFP or the partial CFP (ISO 14067, } \\
\text { 2018) }\end{array}$ & $\begin{array}{l}\text { System boundaries of a carbon } \\
\text { footprint or a partial carbon } \\
\text { footprint apply. System boundaries } \\
\text { include always the intended } \\
\text { customer application. The rebound } \\
\text { effects outside the examined } \\
\text { product system are excluded. }\end{array}$ \\
\hline $\begin{array}{l}\text { Data and data } \\
\text { quality }\end{array}$ & $\begin{array}{l}\text { Actual supplier data } \\
\text { or average data } \\
\text { (UNEP and SETAC, } \\
2011 \text { ) that is as } \\
\text { representative as } \\
\text { possible in terms of } \\
\text { temporal, } \\
\text { technological and } \\
\text { geographical } \\
\text { coverage (ISO } \\
\text { 14044, 2006). }\end{array}$ & $\begin{array}{l}\text { Actual supplier data (UNEP } \\
\text { and SETAC, 2011) that is as } \\
\text { representative as possible } \\
\text { in terms of temporal, } \\
\text { technological and } \\
\text { geographical coverage (ISO } \\
\text { 14044, 2006). }\end{array}$ & $\begin{array}{l}\text { Site-specific data shall be collected } \\
\text { for individual processes where the } \\
\text { organization undertaking the CFP } \\
\text { study has financial or operational } \\
\text { control. The data shall be } \\
\text { representative of the processes for } \\
\text { which they are collected. Site-specific } \\
\text { data should also be used for those } \\
\text { unit processes that are most } \\
\text { important and not under financial or } \\
\text { operational control. (ISO 14067, } \\
\text { 2018.) Data shall be representative as } \\
\text { possible in terms of temporal, } \\
\text { technological and geographical } \\
\text { coverage (ISO 14044, 2006) }\end{array}$ & $\begin{array}{l}\text { Data and data quality requirements } \\
\text { of carbon footprint apply. The data } \\
\text { related to the mechanism that } \\
\text { allows the carbon handprint to be } \\
\text { created shall reflect an existing } \\
\text { operating environment in both } \\
\text { baseline and modified practice. }\end{array}$ \\
\hline $\begin{array}{l}\text { Dealing with } \\
\text { multifunctional } \\
\text { processes or } \\
\text { systems }\end{array}$ & $\begin{array}{l}\text { The } 3 \text { step allocation } \\
\text { procedure (ISO } \\
\text { 14044, 2006; ISO } \\
14067,2018 \text { ) }\end{array}$ & $\begin{array}{l}\text { Usually system expansion } \\
\text { (UNEP and SETAC, 2011) }\end{array}$ & The 3 step allocation procedure (IS & 14044, 2006; ISO 14067, 2018) \\
\hline Time horizon & $\begin{array}{l}\text { Usually applied } \\
\text { retrospectively } \\
\text { (ILCD, 2010; } \\
\text { McManus and } \\
\text { Taylor, 2015) }\end{array}$ & $\begin{array}{l}\text { Usually applied } \\
\text { prospectively (ILCD, 2010). }\end{array}$ & Usually applied retrospectively. & Applied prospectively. \\
\hline $\begin{array}{l}\text { Validity of the } \\
\text { calculation }\end{array}$ & The validity of the ca & $\begin{array}{l}\text { ulation is influenced by the in } \\
\text { (ILCD, 2010) }\end{array}$ & ded application and its requirements & $\begin{array}{l}\text { The handprint is valid as long as the } \\
\text { data used for the calculation is } \\
\text { representative for the examined } \\
\text { situation. }\end{array}$ \\
\hline
\end{tabular}


Carbon handprinting also has limitations. Calculating a carbon handprint can be laborious, as one has to calculate two footprints, both modified practice and the baseline practice, all the way beyond the factory gates. Plus, in doing so, the same difficulties as with carbon footprinting occur, e.g. acquiring reliable data for comparison. This can be challenging, especially for the baseline product system. In addition, when determining the baseline, the conductor of the handprint assessment has to be careful in order to provide reliable results. The baseline has to be reported transparently. This will allow others to conduct handprint assessments for their products with the same baseline. When a customer is offered two alternative solutions for the same use purpose, it must be verified that the same data about the customer's use pattern is used if handprints are to be compared. To support public comparative assertions, a critical review is required in handprinting as well, in accordance with ISO 14040-44. Finally, the term handprint is not widely used or recognized even, so there will be challenges in communicating the handprint results. The second step in this research is to have the calculation guidelines accompanied by communication guidelines. As communicating the handprint of a product in a fair manner is just as important as quantifying it, so we will provide the communication guidelines for carbon handprinting as a next step of the research project.

\section{CONCLUSIONS}

The handprint approach proposed is valid for companies and organizations that are willing to quantify and communicate the environmental benefits of their products, services, or technologies, which they offer to their customers. At this stage, the handprint approach is applicable for assessing greenhouse gas emission reduction, but the future is promising in applying presented handprint thinking to other environmental impacts as well. Especially the ISO standardized water footprint (ISO 14046), which is likely to be convertible to handprinting, with a solid methodology for calculating the potential environmental impacts of water use already existing. The task of applying the handprint approach to other impact categories belongs to upcoming research.

In being extended to other environmental impact categories, the handprint approach could also be applied to a multicriteria product environmental handprint that simultaneously considers several environmental impact categories, in a similar fashion to the product's environmental footprint. Furthermore, the handprint approach could be extended to a more holistic sustainability handprint that considers a product's economic and social handprints alongside the environmental handprint. Through a more holistic approach, trade-offs between different impact categories and compromises between the beneficial impacts on different dimensions of sustainability could be identified and avoided in the sustainable value creation process to the customer.

\section{ACKNOWLEDGEMENTS}

We are grateful for the efforts of the reviewers in helping to guide and improve this manuscript. The work has been conducted as part of a Carbon Handprint project jointly funded by Business Finland, industrial partners (Nokia, KONE, Neste, Paptic, Gasum, Innofive, AM Finland, Biolan, Association of Finnish Steel and Metal Producers, and Sitra), the VTT Technical Research Centre of Finland Ltd and Lappeenranta University of Technology. We would also like to say special thanks to Elizabeth Ernst for proofreading. 


\section{REFERENCES}

16258, SFS-EN., 2012. Methodology for calculation and declaration of energy consumption and GHG emissions of transport services (freight and passengers).

Beckmann, J., 2017. Handabdruck: ein komplementäres Mass positiver Nachhaltigkeitswirkung von Produkten [WWW Document]. URL http://www.handabdruck.org/project_en.php\#project2 (accessed 10.2.17).

Beckmann, J., Eberle, U., Eisenhauer, P., Hahn, R., Hermann, C., Kühnen, M., Schaltegger, S., Schmid, M., Silva, S.L., 2017. Der Handabdruck : Ein Ansatz zur Messung positiver Nachhaltigkeitswirkungen von im Rahmen des Projekts „, Der Handabdruck : ein komplementäres Maß positiver Nachhaltigkeitswirkung von Produkten “.

Biemer, J., Dixon, W., Blackburn, N., 2013. Our environmental handprint - The good we do. 2013 1st IEEE Conf. Technol. Sustain. SusTech 2013 146-153. https://doi.org/10.1109/SusTech.2013.6617312

Bjørn, A., Hauschild, M.Z., 2013. Absolute versus Relative Environmental Sustainability: What can the Cradle-toCradle and Eco-efficiency Concepts Learn from Each Other? Bjørn and Hauschild Cradle to Cradle versus Eco-efficiency. J. Ind. Ecol. 17, 321-332. https://doi.org/10.1111/j.1530-9290.2012.00520.x

Bortel, I., Vavra, J., Takats, M., 2017. Emissions and performance of a passenger car size diesel engine fueled with HVO diesel fuel mixtures, in: 3rd General Meeting and Workshop on SECs in Industry. Praha.

Cronin, J.J., Smith, J.S., Gleim, M.R., Ramirez, E., Martinez, J.D., 2011. Green marketing strategies: An examination of stakeholders and the opportunities they present. J. Acad. Mark. Sci. 39, 158-174. https://doi.org/10.1007/s11747-010-0227-0

Čuček, L., Varbanov, P.S., Klemeš, J.J., Kravanja, Z., 2012. Total footprints-based multi-criteria optimisation of regional biomass energy supply chains. Energy 44, 135-145. https://doi.org/10.1016/J.ENERGY.2012.01.040

Dyllick, T., Hockerts, K., 2002. Beyond the Business Case for Corporate Sustainability. Bus. Strateg. Environ. 11, 130-141. https://doi.org/10.1002/bse.323

Dyllick, T., Muff, K., 2016. Clarifying the Meaning of Sustainable Business: Introducing a Typology From Business-as-Usual to True Business Sustainability. Organ. Environ. 29, 156-174. https://doi.org/10.1177/1086026615575176

Dyllick, T., Rost, Z., 2017. Towards true product sustainability. J. Clean. Prod. 162, 346-360. https://doi.org/10.1016/j.jclepro.2017.05.189

Ekvall, T., Weidema, B.P., 2004. System boundaries and input data in consequential life cycle inventory analysis. Int. J. Life Cycle Assess. 9, 161-171. https://doi.org/10.1007/BF02994190

Hand Print Action Towards Sustainability, n.d. Evolution of Handprint [WWW Document]. URL http://www.handprint.in/handprint_legacy (accessed 6.6.17).

Hartikka, T., Kuronen, M., Kiiski, U., 2012. Technical Performance of HVO (Hydrotreated Vegetable Oil) in Diesel Engines, in: SAE Technical Paper 2012-01-1585.

Hauschild, M.Z., Rosenbaum, R.K., Olsen, S.I., n.d. Life Cycle Assessment : Theory and Practice.

How, B.S, Lam, H.L., 2018. Sustainability evaluation for biomass supply chain synthesis: Novel principal component analysis (PCA) aided optimisation approach. J. Clean. Prod. 189, 941-961. https://doi.org/10.1016/J.JCLEPRO.2018.03.104

How, B.S., Lam, H.L., 2017. Novel evaluation approach for biomass supply chain: An extended application of PCA. Chem. Eng. Trans. 61, 1591-1596. https://doi.org/10.3303/CET1761263 
ICCA, WBCSD, 2013. Addressing the Avoided Emissions Challenge. Guidelines from the chemical industry for accounting for and reporting greenhouse gas (GHG) emissions avoided along the value chain based on comparative studies [WWW Document]. URL https://www.icca-chem.org/wpcontent/uploads/2015/08/Addressing-the-Avoided-Emissions-Challenge.pdf (accessed 3.13.18).

ILCD, 2010. International Reference Life Cycle Data System (ILCD) Handbook -- General guide for Life Cycle Assessment -- Detailed guidance, Constraints. https://doi.org/10.2788/38479

ISO 14046, 2014. Environmental management -- Water footprint -- Principles, requirements and guidelines.

ISO 14040, 2006. Environmental management. Life cycle assessment. Principles and framework.

ISO 14044, 2006. Environmental management. Life cycle assessment. Requirements and guidelines.

ISO 14067, 2013. ISO/TS. Greenhouse gases. Carbon footprint of products. Requirements and guidelines for quantification and communication.

ISO 14067, 2018. Greenhouse gases -- Carbon footprint of products -- Requirements and guidelines for quantification.

Kravanja, Z., Čuček, L., 2013. Multi-objective optimisation for generating sustainable solutions considering total effects on the environment. Appl. Energy 101, 67-80. https://doi.org/10.1016/J.APENERGY.2012.04.025

LIPASTO, 2017. LIPASTO [WWW Document]. LIPASTO traffic Emiss. URL http://lipasto.vtt.fi/ (accessed 12.1.17).

McDonough, W., Braungart, M., 2002a. Design for the Triple Top Line: New Tools for Sustainable Commerce. Corp. Environ. Strateg. 9, 251-258. https://doi.org/10.1016/S1066-7938(02)00069-6

McDonough, W., Braungart, M., 2002b. Cradle to Cradle: Remaking the Way We Make Things, 1st ed. North Point Press, New York.

McManus, M.C., Taylor, C.M., 2015. The changing nature of life cycle assessment. Biomass and Bioenergy 82, 1326. https://doi.org/10.1016/j.biombioe.2015.04.024

Norris, G., 2015. Handprint-Based NetPositive Assessment 17.

Norris, G., 2013. CHAPTER Business and the Common Good: Some Fundamental Issues, in: Groschl, S. (Ed.), Uncertainty, Diversity and the Common Good: Changing Norms and New Leadership Paradigms. Gower Publishing, London.

Outotec, 2015. How do we measure our handprint? - Outotec [WWW Document]. URL https://www.outotec.com/company/sustainability/how-do-we-measure-our-handprint/ (accessed 8.10.18).

Patala, S., Jalkala, A., Keränen, J., Väisänen, S., Tuominen, V., Soukka, R., 2016. Sustainable value propositions: Framework and implications for technology suppliers. Ind. Mark. Manag. 59, 144-156. https://doi.org/10.1016/j.indmarman.2016.03.001

Pexa, M., Čedík, J., Mařík, J., Hönig, V., Horníčková, Š., Kubín, K., 2015. Comparison of the operating characteristics of the internal combustion engine using rapeseed oil methyl ester and hydrogenated oil. Agron. Res. 13, 613-620.

Pihkola, H., Federley, M., Nors, M., Dahlbo, H., Koskela, S., Jouttijärvi, T., 2010. Communicating environmental impacts of print products.

Ramirez, E., Gonzalez, R.J., Moreira, G.J., 2014. Barriers and bridges to the adoption of environmentallysustainable offerings. Ind. Mark. Manag. 43, 16-24. https://doi.org/10.1016/j.indmarman.2013.07.012

Sala, S., Farioli, F., Zamagni, A., 2013. Progress in sustainability science: Lessons learnt from current methodologies for sustainability assessment: Part 1. Int. J. Life Cycle Assess. 18, 1653-1672. https://doi.org/10.1007/s11367-012-0508-6 
Sugiyama, K., Goto, I., Kitano, K., Mogi, K., Honkanen, M., 2012. Effects of Hydrotreated Vegetable Oil (HVO) as Renewable Diesel Fuel on Combustion and Exhaust Emissions in Diesel Engine, in: SAE Int. J. Fuels Lubr. https://doi.org/10.4271/2011-01-1954

Tynkkynen, O., Berninger, K., 2017. Nettopositiivisuus. Menestyvän ja vastuullisen liiketoiminnan uusi taso.

UNEP, SETAC, 2011. Global Guidance Principles for Life Cycle Assessment Databases. A Basis for Greener Processes and Products.

WBCSD, WRI, 2004. The Greenhouse Gas Protocol. A Corporate Accounting and Reporting Standard.

Weidema, B.P., 2003. Market information in life cycle assessment, Danish Ministry of the Environment.

Weidema, B.P., Frees, N., Nielsen, A.-M., 1999. Marginal production technologies for life cycle inventories. Int. J. Life Cycle Assess. 4, 48-56. https://doi.org/10.1007/BF02979395

Young, W., Tilley, F., 2006. Can businesses move beyond efficiency? The shift toward effectiveness and equity in the corporate sustainability debate. Bus. Strateg. Environ. 15, 402-415. https://doi.org/10.1002/bse.510

Zamagni, A., Guinée, J., Heijungs, R., Masoni, P., Raggi, A., 2012. Lights and shadows in consequential LCA. Int. J. Life Cycle Assess. 17, 904-918. https://doi.org/10.1007/s11367-012-0423-x 